\title{
DIETRICH VON BERN: GERMANIC HERO OR MEDIEVAL KING? ON THE SOURCES OF DIETRICHS FLUCHT AND RABENSCHLACHT
}

\author{
NORBERT VOORWINDEN
}

R. v. Rijnlaan 20, 2343 SV, Oegstgeest, The Netherlands

\begin{abstract}
The so-called historical Dietrich epics Dietrichs Flucht and Rabenschlacht, composed in the 13th century, are generally considered to relate stories about Theodoric the Great, King of Italy from 493 till 526, based either on an oral tradition of more than six hundred years or on written sources such as chronicles. An analysis of the texts, however, shows that many of the geographical names occurring in the poems and many of the events described rather seem to reflect the political situation during the reign of Emperor Frederic II (1212-1250).
\end{abstract}

\section{Introduction}

Dietrichs Flucht and Rabenschlacht are the two most important poems of the so-called "historical" Dietrich epics." They were written in the second half of the 13th century and pretend to recount the story of Dietrich von Bern who may be identified with the Ostrogoth Theodoric the Great, King of Italy between 493 and 526. In Dietrichs Flucht Dietrich's uncle Ermrich invades his kingdom, which comprises Lombardy, Istria, Friuli, and the Inn Valley. In spite of his victory in a battle at Milan Dietrich abandons his realm to Ermrich to save the lives of seven of his men captured by the enemy and takes refuge with King Etzel of the Huns. He twice returns to Italy and defeats Ermrich in battles near Milan, Ravenna and Bologna, with armies supplied by Etzel, but withdraws after every victory to King Etzel's court. In Rabenschlacht Dietrich once more leads an army supplied by Etzel into Italy and puts Ermrich to fight at the battle of Ravenna. In the course of this battle Dietrich's brother Diether and the two sons of Etzel are killed by the traitor Witege. Dietrich beheads the knight in whose charge he had left the young princes and pursues Witege, who escapes by riding into the sea. Etzel and his queen, Helche, on Rüdiger's intercession, forgive 
Dietrich the loss of their sons. Dietrich stays at King Etzel's court and has, in spite of three victories, still not succeeded in recovering his kingdom. ${ }^{2}$

These works are called "historical" because they are - according to most scholars - based on historical events. ${ }^{3}$ These historical events are the invasion of Italy by Theodoric with an army in the year 489, three battles against Odoacar, one of them near Verona, one at Ravenna, and the death of one of King Etzel's sons in a battle in 454 in which also Gothic warriors took part. Other parallels are less obvious, such as the treason by Tufa (in the epics Witege), the capturing of a mission sent by Theodoric, and the arrival of an auxiliary army.

Nevertheless, many scholars have tried to reconstruct old heroic poems on which the two Dietrich epics, Dietrichs Flucht and Rabenschlacht, could be based and which - in their opinion have been composed in the days when these events took place or shortly afterwards. This has led to excesses of unbridled fantasy. ${ }^{4}$ Apart from a poem dealing with Dietrich's exile at King Etzel's court and a poem dealing with the death of the sons of King Etzel, which must have existed both around 1200, because the Nibelungenlied refers to the first, ${ }^{5}$ the Nibelungenklage to the second, ${ }^{6}$ it is not necessary to postulate any older version of both epics. Even the arguments in favour of an older poem dealing with Dietrich's flight from his country followed by an exile at King Etzel's court and his return to Italy after thirty years is not undisputed anymore. ${ }^{7}$ Thus, it is not necessary to postulate an uninterrupted oral tradition from the 6th till the 13th centuries, because the few historical facts on which Dietrichs Flucht and Rabenschlacht are based could be found easily in any chronicle. ${ }^{8}$

Not historical in both epics is the name of Dietrich's opponent: Ermrich instead of Odoacar, and not historical is the fact that Dietrich has to leave his country after every battle in which he is victorious. One gets the impression that the author only knew the name Theodoric/Dietrich and the fact that this man had beaten his opponent in three battles in northern Italy. Nevertheless, Italy was still in the hands of the enemy, which means that the necessity to organise campaigns into Italy still exists. It could even have been the goal of the author to demonstrate this. ${ }^{9}$ To make his story as convincing as possible, he needed facts, and especially geographical names, which could enhance the impression that he is telling the truth, that his story is "history". He has succeeded in so far as 
Heinrich von München incorporated parts of Dietrichs Flucht in his chronicle of the world, written in the 14th century. Joachim Heinzle states in his latest book that in this case heroic poetry has gradually become historiography in the sense of the learned tradition. ${ }^{10}$ One could, however, consider the possibility that these two epics - but especially Dietrichs Flucht - were intended from the very beginning as imitations of historiography. The author knew some names, King Theodoric, Verona and Ravenna, and some events, three battles and a traitor, from literary sources and took the rest from other sources. The descriptions of the battles are quite monotonous, and generally based on battle descriptions by classical Latin authors, such as Virgil or Lucanus, and in the descriptions of the three battles the same elements appear over and over again. One gets the impression that the author has tried very hard to compose a lengthy poem out of the scarce material which he had at his disposal.

Many of the details which he mentions, however, deviate considerably from what we normally find in heroic poetry. It is very likely that the author has heard many of these details as well as the great number of geographical names which occur in Dietrichs Flucht from knights who returned from campaigns in Italy in the 13th century. There must have been quite a lot of German knights - and an even greater number of foot-soldiers accompanying those knights - who campaigned in Italy, not only under the reign of Frederic $\mathrm{II}^{11}$ but also under his father, Henry VI, and under his grandfather, Frederic I Barbarossa.

The following chapters will deal with the geographical names in Dietrichs Flucht and, subsequently, with seven details which cannot possibly stem from the heroic tradition but which probably reflect events that happened during the reign of Emperor Frederic II.

\section{Geographical names ${ }^{12}$}

In no Middle High German epic are so many names of Italian regions and towns mentioned as in Dietrichs Flucht. ${ }^{13}$ However, not all the geographical names which occur in the text denote regions and towns in Italy as such. Some of them are used as part of the name of a hero indicating his provenance. ${ }^{14}$ But nevertheless they occur and that means that the author must have heard them somewhere, for most of them do not occur in other heroic poems. ${ }^{15}$

The geographical names are quoted in alphabetical order in Middle High German spelling. In brackets the modern Italian name is added. The names printed in italics occur not only in Dietrichs Flucht but also in Rabenschlacht. 
Ankône (Ancona), Bâdouwe (Padova), Berne (Verona), Bôle (Pola), Bôlonje (Bologna), Botzen (Bolzano), Brandîs (Brindisi), Brissân (Brescia oder Bressanone), ${ }^{16}$ Cêciljenlant (Sicilia), Elsentroye (Troia), ${ }^{17}$ Friûl (Friuli), Gâlaber (Calabria), Garte (Garda), ${ }^{18}$ Heste (Este), Hôhensien (Siena), Isterrî̀ch (Istria), Lamparten (Lombardia), Latrân (Laterano), Lunders (Luni), ${ }^{19}$ Mantouwe (Mantova), Meilân (Milano), Mêrane (Merano),${ }^{20}$ Metzen (Mezzolombardo), ${ }^{21}$ Muntigel (Montecchio Maggiore), ${ }^{22}$ Nônes (Val di Non), ${ }^{23}$ Püllel Püllenlant (Puglia), Rabene (Ravenna), Rôme (Roma), Saders (Zara), Spôlît (Spoleto), Trîente (Trento), Tuscân (Toscana) and Wernhersmarke (Le Marche).

In Dietrichs Flucht we find 33 geographical names denoting towns and regions in Italy, only 13 of them also occur in Rabenschlacht. ${ }^{24}$ Ernst Martin, the first editor of Dietrichs Flucht and Rabenschlacht suggests in his introduction that the author might have made acquaintance with all those Italian geographical names during the last decade of the Hohenstaufen, the decade between the death of the son-in-law of Frederic II, Ezzelino da Romano, who died in 1259, and the death of Konradin/Corradino, who was decapitated in 1268 in the main square in Naples. ${ }^{25}$ But it is not necessary to assume that the author has heard of these geographical names in this decade. Most of them can be connected with the biography of the Emperor Frederic II, who ruled from 1212 till $1250 .^{26}$ During the winter of $1236 / 1237$ Frederic stayed some time in Vienna where he forced the Duke of Austria to resign, and in Austria Dietrichs Flucht and Rabenschlacht were composed.

Frederic was born in Iesi in Le Marche, he was raised in Sicily; Calabria and Puglia were two important regions of his father's kingdom. When he left for Germany he sailed to Rome and from there to Genoa. Then he travelled over land to Cremona where he was welcomed by the margrave of Este. When the Milanese army attacked them, he jumped on a horse and rode to Mantova and from there to Verona and further on to Trento. Since the Dukes of Merano and Bavaria where hostile, he could not use the Brennero, so he took a sort of backroad through the mountains and appeared in Constance without being discovered by his enemies. This little fragment of Frederic's biography already contains eleven names from our list.

Nearly all the other names can be connected with Frederic in a similar way. In Brindisi the army of the crusaders gathered before they set sail for the Holy Land; during the campaigns of Frederic in Lombardia and the rest of northern Italy, Brescia, Milan and Bologna were his strongest opponents; several times he intervened in the Duchy of Spoleto and in Toscana, he stayed some time in Siena, he summoned his vassals at court meetings in Ravenna and in Friuli (mainly in Cividale) and he spent a week at Padua. This abstract of 
Frederic's movements as a political leader contains another eleven names from our list.

If Elsentroye is really Troia in Puglia, then it fits very well into Frederic's biography, because it is in the vicinity of Foggia, Frederic's favourite residence, and not far from Lucera, where Frederic's muslim archers came from. The only places which are more difficult to connect with Frederic are some places in Alto Adige, such as Bolzano, Mezzolombardo, Val di Non and Montiggl. Perhaps these names are taken from the local tradition from which the so-called "adventurous" Dietrich epics stem. ${ }^{27}$

It was not my intention to connect all the geographical names in Dietrichs Flucht without exception with the biography of Frederic II. My only aim was to show that a poet searching for geographical names in those regions of Italy where the battles between Theodoric and Odoacar had taken place in order to provide the story he is telling with an air of historical truth, could have asked any knight returning from one of the campaigns of Frederic II to provide him with those names.

But there are more details in Dietrichs Flucht and Rabenschlacht which are very unusual in heroic poetry, but which seem to be drawn on the reality of the 13 th century.

The strategical significance of Verona

When King Ermrich had decided to conquer Dietrich's lands, he marched with a great army from southern Italy to the north. Puglia and Calabria were his personal heritage, as well as Le Marche, which he had given to a liegeman as a feoff (2432-2434). He moves on to Ravenna and Milan (2861), but his main goal is Verona:

Ermrich swuor einen eit daz er nimmer wolde ûf gehân

od im wurde Berne undertân. (2882-2884)

[Ermrich swore an oath that he would never give up until he had conquered Verona.]

Ermrich takes the city by means of extortion but when Dietrich, who stays at King Etzel's court, receives a message informing him that his partisans have recaptured the town he marches, accompanied by five hundred Hunnish knights, immediately to Verona (5613-5617). The narrator informs us that the journey takes twelve days, but he does not tell us which way they go. It is quite remarkable that Ermrich was so eager to capture Verona, but it is quite remarkable as well that Dietrich marches from King Etzel's court 
straight to Verona. On a journey from Hungary to northern Italy one would expect other places, such as Pola or Treviso, to be mentioned first. Verona, on the other hand, is a bridge-head for an army coming from the north, from Germany.

In the 13th century Verona was of great importance for Frederic II because it dominated the shortest way to Germany, the valley of the Adige and the Brennero. In the autumn of 1237 Frederic II arrived at Verona with an army of 2000 German knights and an even greater number of foot-soldiers. The importance of Verona for Frederic II can hardly be underestimated ${ }^{28}$ and we will hear of this city later on again.

When Dietrich returns the second time to Italy, he marches - as can be expected - through Istria and Pola and the first town in Italy which is mentioned is Padua (8107-8217). This town is occupied by Ermrich's troops under the command of his son, the junge künic Friderîch,the young King Friderich (8234). In the following battle he is defeated and forced to flee to Bologna where he joins his father's army. Dietrich moves on to Ravenna to review the consequences of Ermrich's temporary rule over the town. In Rabenschlacht the same route is described. In this poem again the first encounter with the enemy takes place at Padua. This time the commander of the town is not Friderich but Rumolt, and no battle is fought but a knightly tournament is organised on a meadow outside the city walls instead.

This is another detail reminding us of an event which took place in the beginning of the year 1239, when Frederic II arrived at Padua with his court. During a week he was present at the traditional games held on a meadow outside the city walls. ${ }^{29}$

The change of power in towns

In Rabenschlacht no special reason for Dietrich's campaign is mentioned, apart from his understandable desire to return to his home country. In Dietrichs Flucht Dietrich receives a message that Witege, the man he had appointed commander over Ravenna before leaving Italy, has deserted to the enemy and surrendered the town to Ermrich, who has killed the entire population:

Raben habt ir wider verlorn:

daz hât Witege hin gegeben

und dar zuo al der liute leben,

beidiu wîp unde kint,

alle die in der stat sint, 
die hât Ermrîch erhangen

und lützel ieman gevangen. (7712-7718)

[You have lost Ravenna again: Witege has handed it over to the enemy, together with all the inhabitants, women and children, all people in town have been hanged by Ermrich and hardly anyone has been taken prisoner.]

This is the immediate cause for Dietrich's third campaign against Ermrich. In the 13th century the desertion of Ravenna was the motive for a punitive expedition as well. When Frederic II was staying in Cremona in August 1239, he received the message that Ravenna, which had always been a loyal ally of the Emperor, had seceded and placed itself under the protection of Bologna. The Emperor marched immediately against Bologna devastating the surrounding territories and several castles. ${ }^{30}$

During the first half of the 13th century the desertion of a town or the dismissal of a podestà was often the immediate cause for military action. In 1232 Frederic had succeeded in making his sonin-law Ezzelino da Romano podestà of Verona. This town had till then been a member of the league of Guelf towns, the opponents of Frederic, who was the head of the Ghibelline party. ${ }^{31}$ One year later the population of Verona elected the sermonizer John of Vicenza as their "duke". Shortly after these events the Lombardic war broke out again. ${ }^{32}$ John was removed and taken prisoner, and Verona became a Ghibelline town again. In 1235 Pope Gregory IX appointed a new Guelf podestà in Verona, and Frederic marched once more against the united Lombardic cities. ${ }^{33}$ It is quite remarkable that the Italian word podestà occurs three times in Dietrichs Flucht. ${ }^{34}$ In other Middle High German texts it never appears, apart from one single exception.

\section{The great battles}

Before the beginning of all three great battles in Dietrichs Flucht and before the beginning of the only great battle in Rabenschlacht deliberations take place in which all heroes take part. The main characters suggest tactical measures with which an enemy outnumbering the own army can be faced. Before the first battle, old Hildebrand suggests avoiding an open battle and launching an attack before dawn when the enemy is still asleep. During the campaigns of Frederic II in Lombardy the united forces of the Lombardic cities always tried to avoid an open battle, because their army was in many respects inferior to the imperial army. ${ }^{35}$ 
More interesting, however, is the tactic which Dietrich's advisers propose before the second and the third battles and which is applied again in the only battle in Rabenschlacht. Before the beginning of the second battle Rüdiger proposes splitting the army in two sections:

zweinzic tûsent sendet vür,

die sich legen in ein huote.

und gebiet den helden guote,

daz si sô lange dâ bîten,

unz daz si sehen rîten

die vînde mit gewalte.

und bitet die recken balde,

daz si in der huot sô lange bîten,

und sô wir danne hie gestrîten,

sô suln die nôtvesten

hinden ûf die vînde bresten. (6306-6316)

[Send twenty thousand in advance who must wait in hiding. And tell the good heroes that they must wait there until they see the enemy forces advancing. Ask the brave knights to wait in hiding that long, and as soon as we start fighting here, the brave warriors shall attack the enemy from behind.]

In the third battle the same tactic is applied once more, and again it is Rüdiger who suggests splitting the army:

wir mugen volleclîche hân anderthalp hundert tûsent man:

die sul wir enzwei wegen. (8545-8547)

[All together we may have 150.000 men at our command: we must divide them into two.]

Half of them must stay at the battle field, the other half must ride all night and arrive before dawn at a place in the rear of the enemy army, where they must wait in hiding until the battle has begun. Then they must attack the enemy from behind (8552-8557). During the night they ride über wazzer unde über lant (8685), so it seems that rivers have to be crossed as well. A similar tactic is proposed in Rabenschlacht, not by Rüdiger, however, but by another hero, Helphrich von Lunders. He suggests:

ir sult iuch dar nâch phlihten

und sendet balde after wegen

zweinzic tûsent recken. (stanza 568, 3-5).

[You must do the following: send back as soon as possible twenty thousand warriors.] 
And he continues by saying that they must ride the whole night in order to reach a place behind Ermrich's army before dawn. As soon as the battle begins, they must attack the enemy from behind (stanza 572-573).

In one respect the three proposals are identical: three times dividing the army into two is suggested. One part has to stay on the battle field, the other must ride during the night around the army of the enemy and attack it from behind. A similar trick was executed by Frederic II in the battle at Cortenuova on 27 th November $1237 . .^{36}$ The army of the allied Lombardic cities was encamped near Manerbio, about $25 \mathrm{~km}$ south-west of Brescia, on three sides surrounded by a river with swampy banks. The imperial army was encamped on the other side of the river and tried to provoke the Lombards to leave their safe position, which they did not. At last, Frederic decided to have bridges constructed across the river Oglio and he withdrew his army in the direction of Cremona. When he had the bridges removed again, the Lombards got the impression that Frederic had given up his plan to attack them. Subsequently, they withdrew and marched home in the direction of Milan. But Frederic had split his army, and only a part of it marched into winter-quarters at Cremona, the rest hurried, unseen by the enemy, to Soncino, $30 \mathrm{~km}$ to the west, where they expected the Lombards to cross the river Oglio. The Lombards, however, had chosen a route more to the north, but when Frederic launched a surprise attack on them two days later near Cortenuova, he was able to defeat them.

In the Annales Placentini Gibellini which cover the years 1154 till 1284 the battle of Cortenuova is described as follows:

Deinde imperator super flumen Olii plurimos pontes iussit aptari, et die Lune, 9. Kalendas Decembris proximi, ${ }^{37}$ summo mane precepit populos cum carociis transire, et ipse cum miliciis suis post eos transivit absque bello. Sequenti die missit populos cum carociis abire Cremonam, ipse autem cum miliciis et Saracenis Suncinum properavit. $^{38}$

[Then the Emperor gave the order to build several bridges across the river Oglio and on Monday, 9th December next, he let his men cross the river very early with their waggons, and he crossed the river after them with his soldiers as if he gave up the plan to fight a war. The next day he sent his men with their waggons to Cremona, but he went with his own soldiers and his Saracens quickly to Soncino.]

In this battle he was able to seize the carroccio of the Milanese and among the thousands of prisoners taken was the podestà of 
Milan, Pietro Tiepolo, who was a son of the Doge of Venice. The poor man was kept in prison for twelve years and finally hanged.

Ermrich's attitude towards his son

During the first battle in Dietrichs Flucht the commander of Padua, Ermrich's son Friderich, is taken prisoner by Dietrich. Later Dietrich offers to release him to Ermrich in exchange for seven of his own men who have fallen into Ermrich's hands. The delegation Dietrich sends to Ermrich gets the following answer:

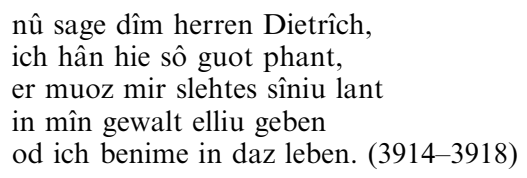

[Now tell your lord Dietrich that I have such a good surety, that he can do nothing but hand over all his lands to me, otherwise I shall kill them.]

Apparently he does not care that his own son will be in great danger in that case. To one of the seven prisoners he had already stated before that he would rather forsake his own son than release his prisoners. Later Ermrich sends his son abroad, sacrificing him, as the narrator tells us in a prediction, but he does not give any details (2457-2466).

The relationship between father and son in these two poems reminds us of the relationship between Frederic II and his eldest son Henry VII. After having roused his father's anger repeatedly by rash actions and after having refused to appear at an assembly of the court at Ravenna in 1232, Frederic forced him to appear at a court meeting in Cividale one year later. There he forced his son to swear loyalty and obedience, but in the autumn of 1234 Henry concluded a treaty with his father's arch-enemy, Milan. Shortly after that, Frederic appeared in Germany with an army. Henry hurried to the castle of Wimpfen, but Frederic refused to see him. He had to appear before the court at Worms. There he fell down on his knees and begged his father to forgive him. But Frederic was without mercy. Henry was arrested and imprisoned in Rocca San Felice near Melfi and later in Nicastro. After six years he was taken from there to another prison, but during the journey he fell off his horse - or jumped in a ravine - and died. ${ }^{39}$ It is not clear whether it was an accident or suicide, but he died without reconciliation with his father. Eye-witnesses describe the scene at Worms as follows: 
...venit filius rex Henricus et corruit pronus ante pedes patris quasi reus lese maiestatis, querens eum gratiam. Cumque diu prostratus in terra iaceret nec ab aliquo levaretur ... ${ }^{40}$

[... the son, King Henry, came and fell down on his father's feet as if he were accused of lese-majesty, begging for mercy. After having been lying on the floor for a long time without anybody telling him to stand up ...]

This scene reminds us of a similar scene in Dietrichs Flucht. After Ermrich has refused to release the seven prisoners, Dietrich himself appears at Ermrich's court and begs for mercy:

daz houpt er dô nider bôt

Ermrîche ûf die vüeze.

er sprach: 'gedenke, veter süeze,

daz ich bin dînes bruoder kint,

[...]

ich wil nimmer mêre

wider dîne hulde iht begên.

ruoche dînes zornes abe gestên.' (4220-4228)

[He bent his head down to Ermrich's feet. He said: 'Dear uncle, do not forget that I am the son of your brother. I shall never again do anything without your consent. Please, don't be angry anymore.']

The same words could have been spoken by Henry VII to his father in Worms, and Ermrich's reaction is exactly the same as Frederic's according to the eye-witnesses already quoted:

lange sweic der künic Ermrîch,

ze leste sprach er unerbarmeclîch:

'nû strîch von mînen ougen!' (4229-4231)

[King Ermrich kept silence for a long time, at last he said without mercy: 'Get out of my sight!']

Especially the fact that both Dietrich and Henry VII remain quite a while lying on the ground waiting for an answer without anyone interfering is a striking similarity.

\section{The vow to undertake a crusade}

In Dietrichs Flucht the Duke of Ravenna, Sibeche, advises Ermrich to send messengers to Dietrich to invite him for a visit. The messengers are instructed to tell Dietrich that his uncle is intending to leave for the Holy Land and to ask him to come and take over the reign during his uncle's absence. Sibeche is sure that Dietrich will comply with this request and he continues: 
als daz danne geschiht, sô beitet dâ mit langer niht, ir scheidet in von dem leben. (2629-2631)

[When this happens, then you shall not hesitate but deprive him of his life.]

In other words: Ermrich must announce a crusade, only to lure Dietrich to his court, but he never has any intention of undertaking a crusade. Apart from the fact that a crusade in Theodoric's days is an anachronism, the announcement of a crusade which one is not prepared to carry out, reminds again of Frederic II. When Frederic, urged by the Pope, finally agreed to sail for the Holy Land in 1227, he fell ill. After having embarked at Brindisi, the Emperor went ashore again at Otranto and stayed in Italy for a while. Pope Gregory IX accused Frederic of breaking his vow and excommunicated him at once. ${ }^{41}$

\section{Substitutional punishment}

In Dietrichs Flucht the young Friderich acts as commander of the troops in Padua. After being defeated by Dietrich he has to give up the town and flees to Bologna to meet his father (8353). During the battle, one of Dietrich's men, Wolfhart, has captured Sabene, the son of Sibeche, who once advised Ermrich to kill Dietrich (2602-2612). Because of the crimes of his father, the son is now hanged in public:

einen galgen machte Wolfhart.

des ungetriuwen Sibechen zart

der wart gehenket dar an.

daz muosten al die sehen an,

die indert wâren in der stat.

des ungetriuwen Sibechen rât

dâ vil übele ûz gie

an sînem sune, den man hie. (8389-8396)

[Wolfhart built a gallows. The son of unloyal Sibeche was hanged there. All the inhabitants of the town had to watch the execution. Thus the advice of unloyal Sibeche had rather unpleasant consequences for his son who was hanged.]

For the substitutional punishment of a son instead of his father there is a parallel in the reality of the 13th century. During the battle of Cortenuova the podestà of Milan was taken prisoner and kept in prison since then as a hostage. ${ }^{42}$ When the Venetians attacked some places on the coast of Puglia in 1240, Frederic gave the order to fetch Pietro Tiepolo from his prison and to hang him on 
the steeple of Trani, which is situated immediately on the sea-front, to ensure that the Venetians would be aware of it. The son was executed to punish his father, and what Frederic intended to achieve happened: the Venetians withdrew their fleet. ${ }^{43}$

\section{Christians and heathens}

In Rabenschlacht we learn at the end of the battle that Ermrich has lost many warriors, Christians as well as heathens (stanza 1124). That is peculiar, because in German heroic poetry only armies which are allied to the Huns consist of Christians and heathens. ${ }^{44}$ Dietrich is the commander of such an army, but in his army heathens are never mentioned. It can hardly be a coincidence that heathens are mentioned as members of Ermrich's army, because Ermrich is king of Puglia and Calabria, just like Frederic II, and in Frederic's army the muslim archers of Lucera played a very important role. ${ }^{45}$ They could have inspired the author to refer to heathens in his poem.

\section{Conclusion}

Apart from the fact that the Austrian author who composed the two so-called "historical" Dietrich epics, Dietrichs Flucht and Rabenschlacht, in the second half of the 13th century had hardly any material available and was forced to use every scrap of a story he could lay hands on, there was a good reason why it could occur to him to connect King Theodoric of the 6th century with Emperor Frederic II of the 13th century: that is the similarity of the legends of their deaths. In one rather late - probably 14th century - Dietrich epic, Der Wunderer, we are told that Dietrich will be abducted one day by a wild horse which will take him to a desert where he has to fight dragons till the Day of Judgement. ${ }^{46}$ In the Dialogi by Pope Gregory the Great we read that people have seen Pope John and Symmachus flinging Theodoric into the crater of Mount Etna. ${ }^{47}$ Otto von Freising incorporates this story in his chronicle and adds yet another version of Theodoric's death according to which somebody has seen him riding on horsback into Mount Etna. ${ }^{48}$ A similar story is told about Frederic II. According to the Franciscan monk Thomas of Ecclestone, a man who was praying on the eastern shore of Sicily saw five thousand horsemen in armour riding into the sea. As soon as they touched the water, it sizzled as if they were red hot. When he asked one of them what was going on, the man told him that it was the Emperor Frederic entering Mount Etna together with his men:

Dixit etiam dictus Frater Mansuetus [...] quod quidam frater stans in orto in oratione in Cicilia vidit maximum exercitum 5 milia militum equitum intrantem 
mare; et crepuit mare, quasi essent omnes ex ere candente; et dictum est ei ab uno eorum, quod fuit Fredericus imperator, qui ivit in montem Ethne; nam eodem tempore mortuus est Fredericus. ${ }^{49}$

[The same friar Mansuetus [...] said that some other friar standing in prayer in the eastern part of Sicily saw a huge army of five thousand horsmen riding into the sea; and the sea roared as if they were all made of red-hot bronze; and he was told by one of them that it was the Emperor Frederic entering Mount Etna; and at the same time Frederic had died.]

According to the legend of St. Bartholomew ${ }^{50}$ Frederic had given the order to destroy all churches of Benevento. One day somebody saw a number of figures coming down from heaven, all dressed in white. When he asked one of them who they were, they said they were the patron saints of the churches which were destroyed and they had just sentenced the Emperor. At the same time Frederic died.

All these stories are inventions of the church. Both men, Theodoric and Frederic II, were sinners and heretics according to the church: Theodoric was an Arian, and Arianism was condemned as heresy by the Councils of Nicaea in 325 and Constantinople in 381, whereas Frederic was all his life under suspicion of being a friend of the muslims. In addition, he had been excommunicated several times.

The events which took place in Italy in the first half of the 13th century have provided the geographical background for the battles between Dietrich and Ermrich, the literary heirs of Theodoric and Odoacar. The correspondences between certain events in the poems and in the reality of the 13th century can be pure coincidence, but the fact that there are so many correspondences seems to exclude coincidence as an explanation. It is, by the way, not necessary to identify Dietrich in all cases with Frederic and Ermrich with his opponents. Dietrich as well as Ermrich exhibit traits of Frederic's character and events which may have inspired the author are equally ascribed either to Dietrich or to Ermrich. Obviously, the author had not the intention to take a certain stand in favour of or against Frederic. Dietrichs Flucht and Rabenschlacht are neither romans à clef nor political pamphlets, they are literary works intended to entertain their public. ${ }^{51}$

\section{Notes}

1. E. Martin (ed.), Deutsches Heldenbuch II. Berlin 1866. Two other poems of this category are Alpharts Tod and Dietrich und Wenezlan. Cf. J. Heinzle, Einführung in die mittelhochdeutsche Dietrichepik. Berlin 1999. 
2. Cf. G.T. Gillespie, A Catalogue of Persons named in German Heroic Literature. Oxford 1973, p. 26.

3. G. Zink, Les légendes hérö̈ques de Dietrich et d'Ermrich. Lyon/Paris 1950, pp. $153-158$.

4. J. Heinzle (note 1), p. 76.

5. In the Nibelungenlied the essential "epic background" to the presence of Dietrich at Attila's court is the supposition that he has taken refuge there from his enemy Odoacar. Cf. N. Thomas, Reading the Nibelungenlied. Durham 1995, p. 69.

6. J. Heinzle (note 1), pp. 76-80.

7. Ute Schwab has convincingly shown that the Old High German Hildebrandslied does not testify to the existence of a legend of Dietrich's return to Italy after an exile at Attila's court. Cf. Ute Schwab, Waffensport, rauba und Dietrichs Schatten. In: Neophilologus 84 (2000), 575-607.

8. For example in Otto von Freising's chronicle; cf. W. Lammers (ed.), Ottonis episcopi frisingensis chronica sive historia de duabus civitatibus/Otto Bischof von Freising, Chronik oder die Geschichte der zwei Staaten. Darmstadt 1972 (Freiherr vom Stein-Gedächtnisausgabe XVI), pp. 376-377.

9. Cf. N. Voorwinden, La fonction de la représentation littéraire du roi Théodoric, in: D. Buschinger (ed.), Histoire et littérature au Moyen Age. Actes du colloque du Centre d'Études Médiévales de l'Université de Picardie (Amiens 20-24 mars 1985). Göppingen 1991, pp. 473-483.

10. J. Heinzle (note 1), pp. 61-63.

11. It is even possible that the poet of Dietrichs Flucht has been among them, because he frequently mentions fighting in tunst, 'mist' (e.g. 6548, 8925, 9170), and nebel, 'fog' (e.g. 3432, 8925), which is a typical weather condition for the Po Valley. The poet attributes it, however, to the hot-headedness of the combattants.

12. Cf. A. Leitzmann, Dietrichs Flucht und Rabenschlacht, in: Zeitschrift für deutsche Philologie 51 (1926), pp. 46-91; on geographical names: pp. 72-76.

13. Even in Biterolf und Dietleip, which contains a great number of geographical names, only eight or nine localities in Italy are mentioned: Berne, Lamparten, Laterân, Meilân, Palerne, Pülle, Rabene and Rôme, and possibly Mêrân. Cf. O. Jänicke (ed.), Deutsches Heldenbuch I. Berlin 1866, pp. 297-306.

14. Elsentroye, Heste, Latrân, Lunders and Metzen.

15. The list contains geographical names of regions and towns in Italy including the German speaking region of Alto Adige (Bolzano, Merano etc.), but also the territories on the other side of the Adriatic which were under Italian, or better, under Venetian control in the Middle Ages (Pola, Zara etc.).

16. The Roman and medieval Latin name of Brescia is Brixia, the German name of Bressanone is Brixen, Old High German Brixina. Cf. G. Gasca Queirazza e.a., Dizionario di toponomastica. Storia e significato dei nomi geografici italiani. Torino 1990, pp. 99.

17. I agree with Leitzmann (note 12) who identifies this place with Troia, about $20 \mathrm{~km}$ south-west of Foggia.

18. Although Garda was of no importance in the Middle Ages, Garte refers to this place and not to the Val Gardena, because it usually appears in combination with the name of another town, e.g. Potzen unde Garte (5497), not with that of a region.

19. According to Leitzmann (note 12), the Etruscan Luni (lat. Luna, adjective lunensis) near La Spezia is meant. More probable, however, Middle High German Lunders refers to London (Old French Lundres); cf. G.T. Gillespie (note 2), p. 67. 
20. In heroic poetry Merâne usually refers to Dalmatia; in the 13th century, however, the audience could also have thought of Meran in southern Tyrol, the residence of a duke.

21. Mezzolombardo, home town of the poet Walther von Metz, about $25 \mathrm{~km}$ north of Trento; cf. Leitzmann (note 12, p.74). This is only the case in Dietrichs Flucht, 4466; in 3016 and 5854, and in Rabenschlacht, stanza 730, Metz in Lorraine is meant, home town of Ortwin von Metz.

22. According to Leitzmann (note 12, p. 75). Montecchio Maggiore is situated about $10 \mathrm{~km}$ west of Vicenza. This is in accordance with the route described in the text. The name could have been mixed up with Montiggl, about $15 \mathrm{~km}$ south of Bolzano.

23. A valley, south-west of Bolzano. Leitzmann (note 12) identifies it with Nonsberg. Val di Non is more likely, however, because the name occurs in one line together with the Inn Valley (5495).

24. In Rabenschlacht there is only one geographical name which does not occur in Dietrichs Flucht: Messîe, which means Messina according to some scholars. But this is not very likely, because it is used to indicate the provenance of brave heroes von Messîe ûz der marke (stanza 486), which means from Messîe in Le Marche or from Messîe in the borders.

25. E. Martin (note 1), p. LII. Martin assumes that both epics were composed by the same author. I agree with Leitzmann (note 12) who has convincingly shown that they were written by two different authors. In my opinion the author of Rabenschlacht knew Dietrichs Flucht and borrowed many details from it.

26. E. Kantorowicz, Kaiser Friedrich II. Berlin 1927; Ergänzungsband: Quellennachweise und Exkurse. Berlin 1931; K.J. Heinisch, Kaiser Friedrich II. in Briefen und Berichten seiner Zeit. Darmstadt 1968; K.J. Heinisch, Kaiser Friedrich II. Sein Leben in zeitgenössischen Berichten. München 198833.(dtv dokumente 2901); A. Sommerlechner, Stupor mundi? Kaiser Friedrich II. und die mittelalterliche Geschichtsschreibung. Wien 1999.

27. Beside the historical Dietrich epics a group of seven poems, the so-called "adventurous" Dietrich epics, has been preserved in which Dietrich has to fight dragons, giants and dwarves. All of these poems are set in the valley of the river Adige. Some of the localities in this area seem to have been transferred to the area where the "historical" Dietrich epics are located: Montiggl > Montecchio, Bressanone > Bescia. Considering the fact that the Old English Waldere-fragments allude to Dietrich's fighting against giants (cf. Ute Schwab, Dietrichs Flucht vor den Ungeheuern im altenglischen 'Waldere', in: K. Zatloukal (ed.), Aventiure-/märchenhafte Dietrichepik. 5. Pöchlarner Heldenliedgespräch, Wien 2000, pp. 131-55) it seems very likely that, in contrast to the prevailing opinion, the "historical" Dietrich epics are a younger offshoot of the "adventurous" Dietrich epics.

28. E. Kantorowicz (note 26), pp. 147, 161 and passim.

29. E. Kantorowicz (note 26), p. 430.

30. E. Kantorowicz (note 26), p. 432.

31. E. Kantorowicz (note 26), p. 355.

32. E. Kantorowicz (note 26), pp. 365-366.

33. E. Kantorowicz (note 26), p. 382.

34. In Dietrichs Flucht 1413, 1426 and 1435; cf. A. Leitzmann (note 12), p. 83.

35. E. Kantorowicz (note 26), p. 399.

36. K. Hadank, Die Schlacht von Cortenuova am 27. November 1237. Dissertation Berlin 1905, pp. 38-40. 
37. 26th November after the calendar reform.

38. G.H. Pertz (ed.), Annales Placentini Gibellini. a.1154-1284 (MGH ss XVIII). Hannover 1863, p. 477.

39. E. Kantorowicz (note 26), pp. 242-243 and 368-372.

40. G.H. Pertz (ed.), Gotifredi Viterbiensis opera. Continuatio Funiacensis et Eberbacensis. Historici Germaniae saec. XII (MGH ss XXII). Hannover 1872, p. 348.

41. E. Kantorowicz (note 26), p. 158.

42. K.J. Heinisch 1988 (note 26), pp. 61 and 244.

43. K.J. Heinisch 1988 (note 26), pp. 246 and 313.

44. The word heiden, 'heathen', does not occur in Dietrichs Flucht; in Rabenschlacht it is, in addition, used twice in a comparison: something is that pitiful that even a wild heathen would have cried (stanzas 987 and 1080).

45. E. Kantorowicz (note 26), pp. 121-123.

46. Der Wunderer, stanza 131; cf. G. Zink (ed.), Le Wunderer. Facsimile de l'édition de 1503. Avec introduction, notes et bibliographie. Paris 1949.

47. J.P. Migne (ed.), Sancti Gregorii Papae I cognomento magni opera omnia, tomus tertius. Paris 1896 , pp. $368-369$.

48. “ ... iuxta Gregorii Dialogum a Iohanne et Simacho in Ethnam precipitatus a quodam homine Dei cernitur. Hinc puto fabulam illam traductam, qua vulgo dicitur Theodoricus vivus equo sedens ad infernos descendisse." W. Lammers (note 8), pp. 380-381.

49. F. Liebermann (ed.), Ex Thomae de Eccleston libro de adventu fratrum minorum in Angliam (MGH ss XXXVIII). Hannover 1888, p. 568.

50. Die Legenda aurea des Jacobus de Voragine. Aus dem Lateinischen übersetzt von Richard Benz. Heidelberg 1975, p. 629.

51. A special word of thanks is due to Dr Alan Robertshaw (University of Exeter) for his critical remarks concerning language and contents of this article. 